\title{
Standardization of field conditions and time of sowing on nursery growth of Asparagus racemosus Willd under mid hills conditions of Himachal Pradesh
}

\author{
Usha Thakur*, Meenu Sood ${ }^{1}$ and Jadhav Rani ${ }^{2}$ \\ G. B. Pant National Institute of Himalayan Environment, Himachal Regional Centre, Mohal-Kullu (H.P.) India \\ (Email: ushauhf@yahoo.in)
}

\begin{abstract}
For successful introduction and cultivation of the plant in a new region, the knowledge about the parameters related to the planting material and its growth in that region is very important viz., time of sowing, conditions of growth etc. Keeping in mind the basic requirements and the need to introduce the Asparagus racemosus Willd. from the tropical region to mid hill conditions, the experiment was conducted in the experimental farm of department of Forest Products, College of Forestry, Dr. Y. S. Parmar University of Horticulture and Forestry, Nauni, Solan which falls under mid hill zone of Himachal Pradesh. Seeds were sown under open and protected conditions from March month upto July in growing media (Soil + Cocopeat + Vermicompost (1:1:1)) and observation were recorded after 60 days of seed sowing. It was revealed that maximum germination percentage (31.33), maximum seedling shoot $(23.13 \mathrm{~cm})$ and root length $(11.10 \mathrm{~cm})$ was recorded during May month under protected conditions. There was $840.84 \%, 539.73 \%$ and $205.79 \%$ increase over control in emergence percentage, shoot length and root length, respectively.

Key Words : Asparagus, Field conditions, Germination, Protected conditions, Root length, Shoot length

View Point Article : Thakur, Usha, Sood, Meenu and Rani, Jadhav (2021). Standardization of field conditions and time of sowing on nursery growth of Asparagus racemosus Willd under mid hills conditions of Himachal Pradesh. Internat. J. agric. Sci., 17 (2) : 359-364, DOI:10.15740/ HAS/IJAS/17.2/359-364. Copyright@2021: Hind Agri-Horticultural Society.
\end{abstract}

Article History : Received : 25.02.2021; Revised : 27.02.2021; Accepted : 16.03.2021

\footnotetext{
* Author for correspondence :

${ }^{1}$ Department of Forest Products, Dr. Y.S. Parmar University of Horticulture and Forestry, Nauni, Solan (H.P.) India

${ }^{2}$ P.G. Institute of Post Harvest Management (Dr. BSKKV), Killa- Roha (M.S.) India
} 